Bulletin of the Natural History Museum, 2020, 13: 267-280.

Received 27 Jul 2020; Accepted 26 Oct 2020.

doi:10.5937/bnhmb2013267G

UDC: 598.1(497.16)"2019"

Original scientific paper

\title{
DIVERSITY OF REPTILES IN THE SETTLEMENT MAREZA (MONTENEGRO)
}

\author{
GVOZDENOVIĆ SLAĐANA
}

Montenegrin Ecologists Society, Bulevar Sv. Petra Cetinjskog 73, 81000 Podgorica, Montenegro, e-mail: sladjana87gvozdenovic@gmail.com

Diversity of reptile fauna, as well as threat factors were investigated during April and May 2019 in the settlement Mareza. Field methodology included active searching and visual observation of species along defined transects. In total, 20 reptile species were recorded, what comprises about $55 \%$ of reptile fauna known for Montenegro. According to obtained results, area of Mareza can be considered as important reptile diversity hotspot in Montenegro. First finding of Xerotyphlops vermicularis in this area contribute to knowledge of its distribution range. Three identified species (Emys orbicularis, Testudo hermanni and Elaphe quatuorlineata) are listed on Annex II of the Habitat Directive. None of identified species are vulnerable, endangered or critically endangered, upon the IUCN Red List. Almost all identified species are protected on national level. Main threat factors for reptile fauna in the area of Mareza are: urbanization, habitat fragmentation and destruction, fires, illegal landfills, direct killing by locals and road killing.

Key words: reptile fauna, biodiversity hotspot, Mareza, threat factors

\section{INTRODUCTION}

Settlement Mareza is situated in the central part of Montenegro (municipality of Podgorica). It is situated on north-west part of Podgorica, about $5 \mathrm{~km}$ far away from the town centre, at app. $40 \mathrm{~m}$ above sea level. The site is a complex of freshwater, terrestrial and karst habitats and 
includes flooded and occasionally flooded meadows, canals, streams and springs which together support a number of endemic or otherwise notable species considered unique in the central region of Montenegro (Evans et al. 2019). In the foot of the hill called Velje brdo, numerous perennial and intermittent springs are present which form river Mareza, which flow is partly channelled. In the vicinity of river Mareza is also river Matica. Areas of river Mareza and river Matica are localities where preserved stands of vegetation of aquatic and wet habitats are still present (Stešević et al. 2017). The peripheral part consists of limestone hills, with vegetation of shrubs and semi-shrubs (mainly associations Paliuretum adriaticum and Rusco-carpinetum) (Stešević et al. 2017). This areas are potentially Natura 2000 sites, since some important Natura 2000 habitats (e.g. 3260 and 6420) are present here (Stešević et al. 2017). In 2019, areas of river Mareza and river Matica were protected as Nature Park (Nature Park valley of river Zeta) (AZPŽS 2019).

Both, the aquatic/semi-aquatic habitats and the drier karst/meadow areas, are considered as ecologically important with the Karst elevations (not exposed to flooding) and considered to be particularly important wintering places for amphibians and reptiles (Evans et al. 2019).

Although areas of river Mareza and river Matica are in the vicinity of the capital city and are easily accessible with developed road infrastructure, they have been poorly and partially herpetologically explored (Iković et al. 2016, Stešević et al. 2017, AZPŽS 2019, Evans et al. 2019).

The main goal of this paper is to present reptile diversity and list of main threat factors to reptile populations in the settlement Mareza, including areas of river Mareza and river Matica.

\section{MATERIAL AND METHODS}

Data about diversity of reptiles in the settlement Mareza were collected during field survey in the period April-May 2019. Study area covered 15.8 $\mathrm{km}^{2}$ (Fig. 1). Field survey lasted ten days. Each day, eight hours were spent in the field, mainly by one person. Additionally, due to the ecology of some species (e.g. Hemidactylus turcicus and Telescopus fallax), field survey were conducted during two nights (from $9 \mathrm{pm}$ to $11 \mathrm{pm}$ ). Methodology included active searching and visual observation of species along defined transects as well as observation of road killed specimens. For aquatic species (i.e. turtles), traps - hoop-nets were used (Mali et al. 2014). Traps were baited with hot dogs, and checked on the end of each day. With bait, plastic bottles were placed inside the traps to ensure that they are on the surface of water body, so turtles caught in traps can breathe. Species identi- 
fication was done according to standard herpetological literature (Arnold \& Ovenden 2002). Taxonomy and nomenclature were given according to Speybroek et al. (2020). Anguis fragilis and A. graeca were threated as complex (i.e. Anguis fragilis complex), because further research regarding taxa distinction are required (Siellero et al. 2014, Jablonski et al. 2016). Additionally, Lacerta viridis-bilineata complex which occur in the Western Balkans including Montenegro, were threated as Lacerta viridis complex because further taxonomy evaluation is required (Marzahn et al. 2016).

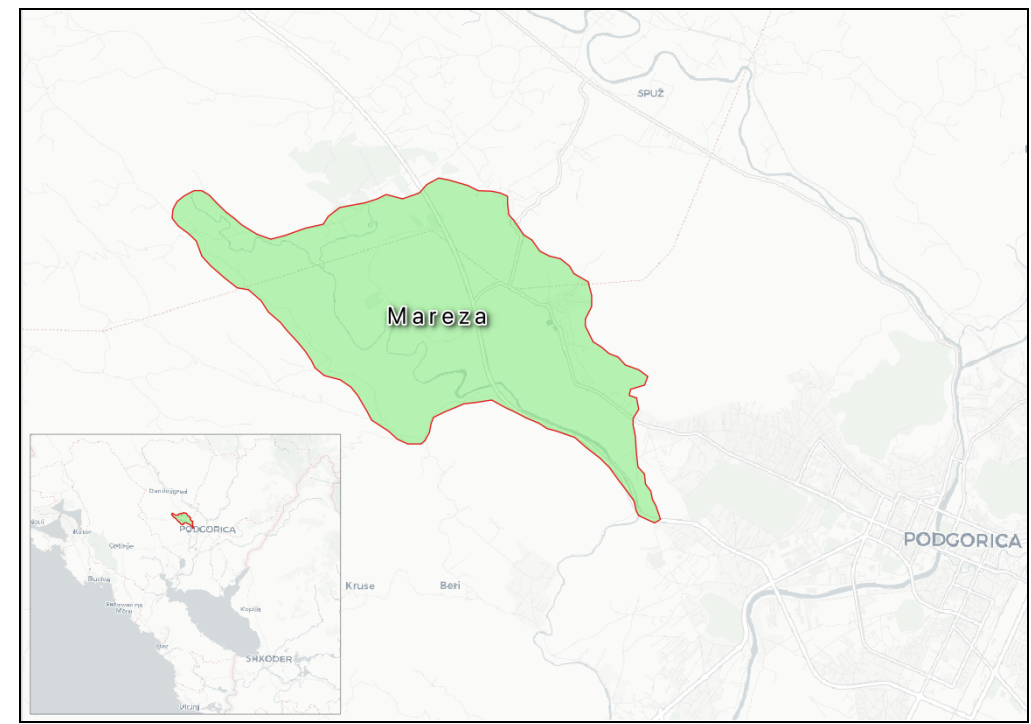

Fig. 1. - Study area

\section{RESULTS AND DISCUSSION}

\section{Analysis of taxa and specimens}

\section{TESTUDINES}

\section{Fam. Emydidae}

Emys orbicularis (Linnaeus, 1758) - in total, 9 individuals, as well as four road killed were found in and near freshwater habitats: river Matica, river Mareza, wetlands, canals and ponds.

\section{Fam. Testudinidae}

Testudo hermanni Gmelin 1789 - in total, 78 individuals, as well as one road killed and two dead (empty shells) were found in all terrestrial habitats: bushes, meadows, human settlements, road edges, river valleys and degraded forests. 


\section{SQUAMATA \\ Fam. Gekkonidae}

Hemidactylus turcicus (Linnaeus, 1758) - only two individuals were found in human settlements on house walls.

\section{Fam. Anguidae}

Anguis fragilis complex - just two individuals, as well as two road killed were found on wet habitats, bellow stones, and on wood pallets.

Pseudopus apodus (Pallas, 1755) - in total, 47 individuals, as well as five road killed were found in all terrestrial habitats: bushes, rocky walls, meadows, human settlements, road edges, river valleys and degraded forests.

\section{Fam. Lacertidae}

Dalmatolacerta oxycephala Duméril and Bibron, 1839 - 12 individuals were found on karst stones, aggregation of rocks and on house walls.

Lacerta trilineata Bedriaga, 1886 - in total, about 40 individuals were found, as well as three road killed in all terrestrial habitats: bushes, rocky walls, meadows, human settlements, road edges, river valleys and degraded forests.

Lacerta viridis complex - only two individuals were found on rocky habitats in degraded forests.

Podarcis muralis (Laurenti, 1768) - in total, 14 individuals were found on rocky habitats, rocky walls, human settlements, on waste and construction landfills, as well as road edges.

Podarcis melisellensis (Braun, 1877) - in total, about 40 individuals, as well as one road killed were found on rocky habitats, rocky walls, human settlements, on waste and construction landfills, road edges, meadow edges.

\section{Fam. Colubridae}

Dolichopis caspius (Gmelin, 1789) - in total, six individuals, as well as one road killed were found on open dry habitat, meadows, road edges, as well as on construction landfills.

Elaphe quatuorlineata (Bonnaterre, 1790) - three individuals were found among wet habitats in area of river Mareza, as well as in degraded forests.

Hierophis gemonensis (Laurenti, 1768) - eight individuals were found on rocky walls with dense vegetation.

Platyceps najadum (Eichwald, 1831) - three individuals, as well as one shedded skin were found on rocky habitats with dense vegetation. 
Telescopus fallax (Fleischmann, 1831) - only one road killed individual was found in human settlement.

\section{Fam. Psammophiidae}

Malpolon insignitus (Geoffroy Saint-Hilaire, 1827) - one individual was found on open rocky habitat, while one road killed individual was found in human settlement.

\section{Fam. Natricidae}

Natrix natrix (Linnaeus, 1758) - in total, 13 individuals were found in and near freshwater habitats (canals, rivers, ponds, wetlands), in bushes, on meadows and among abandoned houses far away from aquatic habitats.

Natrix tessellata (Laurenti, 1768) - in total, 21 individuals, as well as six road killed were found in freshwater habitats (canals, rivers, ponds, wetlands), as well as near freshwater habitats in dense bushes.

\section{Fam. Viperidae}

Vipera ammodytes (Linnaeus, 1758) - three individuals were found on rocky habitats covered with dense vegetation.

\section{Fam. Typhlopidae}

Xerotyphlops vermicularis (Merrem, 1820) - only two individuals were found bellow stone on open habitat near road edge, which is actually part of human settlement.

According to results of ten days field survey, 20 reptile species were recorded in the study area, what comprises about $55 \%$ of reptile fauna in Montenegro (Jovanović 2009, Polović \& Ljubisavljević 2010, Jelić et al. 2013, Žagar et al. 2013, Gvozdenović \& Čavor 2015, Gvozdenović et al. 2016, Iković et al. 2016, Verligov et al. 2016, Džukić et al. 2017, Crnobrnja-Isalović et al. 2018, Iković 2018, Iković \& Gvozdenović 2018, Ljubisavljević et al. 2018). Upon literature sources, 37 reptile species are officially confirmed for Montenegro. In this list, three potentially present species (Tarentola mauritanica, Mediodactylus kotschyi and Podarcis tauricus) are not included (Polović \& Ljubisavljević 2010, Ljubisavljević et al. 2018).

Having in mind that study area is small (including areas of river Mareza and river Matica) and that 20 reptile species are recorded here, area of Mareza should be considered among three areas of the highest reptile diversity in Montenegro, together with Skadar Lake region and Bjelopavlići region (Tomović et al. 2004, Jovanović 2009, Polović \& Ljubisavljević 2010, Polović \& Čađenović 2013, 2014a, 2014b, Iković et al. 2016, Crnobrnja-Isalović et al. 2018, Iković 2018). Reviewing of literature data 
(Stešević et al. 2017) showed that two additional species were recorded in area of Mareza, Algyroides nigropunctatus and Zamenis situla. With 22 officially confirmed species, area of Mareza should be considered as reptile diversity hot spot in Montenegro.

All recorded species belong to two orders (Testudines and Squamata) and ten families (two Testudines, three Lacertilia and five Serpentes). In total, 334 specimens were found. From that number, 217 specimens $(65 \%)$ belonged to four species (Testudo hermanni, Pseudopus apodus, Lacerta trilineata and Podarcis melisellensis). Nine species had low contribution, in range of 0.3 to $1.2 \%$ which correspond to $1-4$ specimens records. Only one species had just one record, Telescopus fallax. According to Stešević et al. (2017) population of this species is widely represented in area of Mareza. This disagreement is most probably due to the fact that species is active during late afternoon and night, while field work for this study were most often conducted during the day time.

Finding of Xerotyphlops vermicularis in this area contribute to the knowledge of its distribution range. $X$. vermicularis is Eurasian species, occurs from Tajikistan, Uzbekistan, Afghanistan and Turkmenistan on east up to Albania, Macedonia and Montenegro on the west (IUCN 2020). In Montenegro, $X$. vermicularis occurs in its southern and south-eastern part (Crnobrnja-Isalović i Džukić 1995, Mrdak 2006, Polović \& Ljubisavljević 2010, Džukić et al. 2017, Crnobrnja-Isalović et al. 2018, IUCN 2020). Although, Grillitsch et al. (1999) published a record of X. vermicularis on Dugi Otok island in Croatia, Jelić et al. (2015) consider this record as highly questionable. Additionally, recent field research failed to confirm presence of this species in the Croatia (Štih et al. 2013, Schmidt et al. 2020), what indicate that the occurrence of this species is very unlikely in Croatia. Also, according IUCN (2020) presence of the species is uncertain for Bosnia and Herzegovina. Having in mind all of facts mentioned above, record of $X$. vermicularis in the area of Mareza is actually on the western boundary of the species distribution range.

Among 334 specimens, 25 specimens were road killed, and two were found dead (two empty shells of Testudo hermanni). The highest number of road killed specimens belong to Natrix tessellata (6 specimens) and Pseudopus apodus (5 specimens). Having in mind that road infrastructure is near river Mareza and surrounding wet habitats, it is not surprising that the highest road killed specimens belong to Natrix tessellata. Road trafic is one of the human activity which, more than ever, leads to decrease of reptile populations (Iković et al. 2012) as it cause habitat fragmentation. Iković et al. (2012) indicated that in the Bjelopavlići region (central Montenegro) most affected reptile species by road infrastructure are Testudo hermanni and Podarcis melisellensis. Evans et al. (2019) also pointed that in area of 
Mareza Testudo hermanni is the most affected reptile species by road infrastructure.

Four out of 20 recorded species belong to Balkan endemic species: Dalmatolacerta oxycephala, Lacerta trilineata, Podarcis melisellensis and Hierophis gemonensis.

\section{Species conservation status}

Most of reptile species (15 species), recorded in the area of Mareza are protected by law in Montenegro (Official Gazette of the Republic of Montenegro 76/06) (Table 1). List of protected species is adopted in 2006 and needs revision in context of consistency, as well as concerning taxonomy and nomenclature. In total, 12 out of 20 recorded species are included in Annexes (II and/or IV) of the Habitat Directive (Table 1). All identified species are included in Appendixes (II and III) of the Bern Convention, while only one species (Testudo hermanni) is included in Appendix II of the CITES list (Table 1).

According to European IUCN Red List (Cox \& Temple, 2009) most of recorded species in area of Mareza are considered as least concerned (LC), while only three species (Emys orbicularis, Testudo hermanni and Elaphe quatuorlineata) are considered as near threatened (NT) (Table 1). These species should be carefully monitored in the future, since their distribution ranges and/or quality of habitats are already impacted by threatening factors in Montenegro (Crnobrnja-Isalović et al. 2018).

\section{Threat factors}

During field survey in the area of Mareza different threat factors for reptile populations were identified: urbanization, habitat fragmentation and destruction, road constructions and road killings, fires, illegal landfills, as well as direct killing by local inhabitants.

Intensive urbanisation and road infrastructure cause habitat fragmentations and habitat destructions, which lead to decrease of reptile populations and diversity loss (Irwin et al. 2010, Iković et al. 2012, French et al. 2018). Roads are often constructed trough reptile habitats and specimens are forced to cross them for migrations among habitats (for mating, egg laying, feeding, hibernation). It is well-known that road mortality is globally high in turtle and snake populations (Aresco 2003, Gibbs \& Steen 2005, Andrews \& Gibbons 2008, Iković 2012, Iković et al. 2012, Vujović et al. 2015). Road infrastructures in area of Mareza do not have technical solutions e.g. eco-tunnels bellow road, trough which specimens can move freely among habitats, or traffic signs and information tables. According to 
Iković (2012) and Iković et al. (2012) eco-tunnels bellow road, as one of the important technical solutions, have to be implemented at appropriate locations at road M18 which passing near the settlement Mareza.

Table 1. - The list of reptile species identified during field work in the study area, national/international protection and conservation status.

\begin{tabular}{|c|c|c|c|c|c|}
\hline \multirow[b]{2}{*}{ Scientific name } & \multirow{2}{*}{$\begin{array}{c}\text { Protection on } \\
\text { national level }^{1}\end{array}$} & \multicolumn{3}{|c|}{ Protection on international level ${ }^{2}$} & \multirow{2}{*}{$\begin{array}{c}\text { IUCN } \\
\text { (Europe) }\end{array}$} \\
\hline & & $\begin{array}{c}\text { Habitat } \\
\text { directive }\end{array}$ & $\begin{array}{c}\text { Bern } \\
\text { convention } \\
\end{array}$ & CITES & \\
\hline Emys orbicularis & + & Annex II, IV & Appendix II & - & NT \\
\hline Testudo hermanni & + & Annex II, IV & Appendix II & Appendix II & NT \\
\hline Hemidactylus turcicus & - & - & Appendix III & - & $\mathrm{LC}$ \\
\hline Anguis fragilis complex & + & - & Appendix III & - & $\mathrm{LC}$ \\
\hline Pseudopus apodus & + & Annex IV & Appendix II & - & $\mathrm{LC}$ \\
\hline $\begin{array}{l}\text { Dalmatolacerta } \\
\text { oxycephala }\end{array}$ & + & - & Appendix III & - & $\mathrm{LC}$ \\
\hline Lacerta trilineata & + & Annex IV & Appendix II & - & $\mathrm{LC}$ \\
\hline Lacerta viridis complex & + & Annex IV & Appendix II & - & $\mathrm{LC}$ \\
\hline Podarcis muralis & + & - & Appendix II & - & $\mathrm{LC}$ \\
\hline Podarcis melisellensis & + & Annex IV & Appendix II & - & $\mathrm{LC}$ \\
\hline Dolichopis caspius & - & Annex IV & Appendix III & - & $\mathrm{LC}$ \\
\hline Elaphe quatuorlineata & + & Annex II, IV & Appendix II & & NT \\
\hline Hierophis gemonensis & + & - & Appendix II & - & $\mathrm{LC}$ \\
\hline Malpolon insignitus & + & - & Appendix III & - & $\mathrm{LC}$ \\
\hline Natrix natrix & + & - & Appendix III & - & $\mathrm{LC}$ \\
\hline Natrix tessellata & + & Annex IV & Appendix II & - & $\mathrm{LC}$ \\
\hline Platyceps najadum & + & Annex IV & Appendix II & - & $\mathrm{LC}$ \\
\hline Telescopus fallax & - & Annex IV & Appendix II & - & $\mathrm{LC}$ \\
\hline Vipera ammodytes & - & Annex IV & Appendix II & - & $\mathrm{LC}$ \\
\hline Xerotyphlops vermicularis & - & - & Appendix III & - & $\mathrm{LC}$ \\
\hline
\end{tabular}

${ }^{1}$ Protection on national level: Official Gazette of the Republic of Montenegro 76/06, 12 December 2006;

${ }^{2}$ Protection on international level: Habitat directive - Council Directive 92/43/EEC of 21 May 1992 on the conservation of natural habitats and of wildlife and flora Habitats Directive - 92/43/EEC, Annex II - animal and plant species of community interest whose conservation requires the designation of special areas of conservation, Annex IV - animal and plant species of community interest in need of strict protection; Bern convention-Convention on the conservation of European wildlife and natural habitats, 1979, Bern, Switzerland, Appendix II -strictly protected fauna species, Appendix III - protected fauna species; CITES - The convention on international trade in endangered species of wild fauna and flora, Appendix II - species that should be under the control of trade to avoid the threat of extinction;

${ }^{3}$ IUCN (Europe): Europe Red List of Reptiles (Cox \& Temple 2009), LC - least concern, NT - near threatened

In the study area, there is huge number of illegal landfills (different types of waste). Some of freshwater canals and meadows are covered by 
solid waste. Also huge number of construction, as well as plastic waste was identified. Landfills cause degradation of habitats, and according to Gibbson et al. (2000) and Brennan \& Kuvlesky (2005) degradation, or alteration of habitats are leading causes of loss of biodiversity. In Montenegro illegal landfills are result of negligent behaviour of humans, and lack of legislations which address waste issue.

On the surrounding hills, fires are common, especially during dry, summer season. Fires are also caused by locals due to the clearing of their properties. Fires are important threat factor to reptiles, especially for slow moving species such as Testudo hermanni. Vujović et al. (2015) found high mortality rate of Testudo hermanni, especially in juveniles, caused by fires in area of town Danilovgrad. According to Cheyland (1984), several largescale fires can eliminate up to $85 \%$ of the population of tortoises in a single year.

In area of Mareza locals often cause destruction of bushes and other vegetation in and around human settlements which are important habitats for numerous reptile species such as Testudo hermanni, Pseudopus apodus, Lacerta trilineata, Lacerta viridis, Hierophis gemonensis, Vipera ammodytes. Killing of reptiles (mainly snakes) is usual because of fear which is caused by ignorance. For locals, all snakes are dangerous/poisonous and should be killed. It is known that killing of snakes by locals contributes to loss of biodiversity (Pandey et al. 2016).

Džukić (1995) listed general measures which should be implemented in term of reptile diversity protection: field surveys in order to collect data about populations, their status and threat factors; protection of natural habitats, especially sensitive ecosystems; law legislations and their application especially in protected areas; revision of law legislation in accordance to science results; separation of special protected zones; restrictions in biocide use; control of fires, urbanization, and pasture; education of locals; control of hunting, illegal collection and trade.

\section{Acknowledgement}

This work was supported by the project "Edukativna stanica Mareza" implemented by NGO "Centre for protection and research of birds in Montenegro", supported by ReLOaD program and financed by Europe Union. Many thanks to Marko Nikolić, Vuk Iković, Katarina Ljubisavljević, Marija Šoškić, Ljiljana Gvozdenović and Milica Pavićević for providing some data and helped in the field work and to Mihajlo Jovićević who provided the map of the study area in GIS program. The author also thanks to reviewer who improved the paper with constructive comments. 


\section{REFERENCES}

Aresco, M. J. (2003): Highway mortality of turtles and other herpetofauna at Lake Jackson, Florida, USA and the efficacy of a temporary fence/culvert system to reduce road kills. In: Irwin, C. L., Garrett, P., McDermott, K. P. (ed.): Proceedings of the International Conference on Ecology and Transportation: 433-449. - Raleigh (NC): Center for Transportation and the Environment, North Carolina State University, New York.

Andrews, K. M., Gibbons, J. W. (2008): Roads as catalysts of urbanization: snakes on roads face differential impacts due to inter- and intraspecific ecological attributes. In: Mitchell, J. C., Jung, R. E. (ed.): Urban herpetology, herpetological conservation 3. - Salt Lake City (UT): Society for the Study of Amphibians and Reptiles.

Arnold, E. N., Ovenden, D. (2002): A field guide to the Reptiles and Amphibians of Britain and Europe. - Harper Collins Publishers, London.

AZPŽS (2019): Studija zaštite zaštićenog prirodnog dobra dolina rijeke Zete. Agencija za zaštitu prirode i životne sredine Crne Gore, Podgorica. [In Montenegrin]

Brennan, L. A., Kuvlesky, W. P. (2005): North American grassland birds: An unfolding conservation crisis?. - Journal of Wildlife Management 69: 1-13.

Cheylan, M. (1984): The true status and future of Hermann's tortoise Testudo hermanni robertmertensi Wermuth 1952 in western Europe. - AmphibiaReptilia 5: 17-26.

Cox, N. A., Temple, H. J. (2009): European Red list of Reptiles. - Office for Official Publications of the European Communities, Luxembourg.

Crnobrnja-Isailović, J., Džukić, G. (1995): First report about conservation status of herpetofauna in the Skadar Lake Region (Montenegro): Current situation and perspectives. In: Llorente, G., Montori, A., Santos, X., Carretero, M. A. (eds): Scientia Herpetologica. - Asociación Herpetológica Española, Barcelona.

Crnobrnja-Isalović, J., Polović, L., Ljubisavljević, K., Čađenović, N., Čuburić, T., Haxhiu, I. (2018): Diversity and conservation status of batrachofauna and herpetofauna in the Lake Skadar region. In: Pešić, V. (ed.): The Skadar/Shkodra Lake Environment. 80. - Springer International Publishing, Cham.

Džukić, G. (1995): Diverzitet vodozemaca i gmizavaca Jugoslavije sa pregledom vrsta od međunarodnog značaja. In: Stevanović, V., Vasić, V. (ed.): Biodiverzitet Jugoslavije sa pregledom vrsta od međunarodnog značaja. - Biološki fakultet i Ecolibri, Beograd. [In Serbian]

Džukić, G., Tomović, Lj., Anđelković, M., Urošević, A., Nikolić, S., Kalezić, M. (2017): The herpetological collection of the Institute for Biological Research "Siniša Stanković", University of Belgrade. - Bulletin of the Natural History Museum 10: 57-104.

Evans, R., Brown, L., King, M. (2019): Main road reconstruction project, rehabilitation and upgrade of the Danilovgrad-Podgorica road section. Framework biodiversity action plan. - European Bank of Reconstruction and 
Development, London. [file:///C:/Users/User/Downloads/PD-DG_BAP\%20(E NG)\%20Final\%20pdf\%20(1).pdf]

French, S. S., Webb, A. C., Hudson, S. B., Virgin, E. E. (2018): Town and country reptiles: A review of reptilian responses to urbanization. - Integrative and Comparative Biology 58(5): 948-966.

Gibbons, J. W., Scoot, D. E., Ryan, T. J., Buhlmann, K. A., Tuberville, T. D., Metts, B. S., Green, J. L., Mills, T., Leiden, Y., Poppy, S., Winne, C. T. (2000): The global decline of reptiles, déjà vu amphibians. - Bio Science 50: 653-666.

Gibbs, J. P., Steen, D. A. (2005): Historical trends in turtle sex ratios in the United States: Long-term implications of road mortality. - Conservation Biology 19: $552-556$.

Gvozdenović, S., Čavor, N. (2015): First record of dicephalism in the four-lined snake Elaphe quatuorlineata Lacépède, 1789 (Serpentes: Colubridae) from Montenegro. - Natura Sloveniae 17(1): 49-50.

Gvozdenović, S., Đurović, M., Iković, V. (2016): Distribution records of sea turtles in the Montenegrin waters. - Studia Marina 29(1): 33-46.

Iković, V. (2012): Uticaj saobraćaja na batraho i herpetofaunu Bjelopavlića. Univerzitet Crne Gore, Prirodno-matematički fakultet. [In Montenegrin]

Iković, V., Pešić, V., Tomović, Lj. (2012): Impact of traffic on herpethophauna and batrachophauna in Bjelopavlici (Montenegro). In: Anonymous (ed.): $4^{\text {th }}$ Congress of the ecologists of Macedonia, with international participation. (Abstract)

Iković, V., Tomović, Lj., Ljubisavljević, K. (2016): Contribution to the knowledge of the batracho- and herpetofauna of the Bjelopavlići region (Montenegro). Bulletin of the Natural History Museum 9: 113-125.

Iković, V. (2018): Izvještaj o stanju herpetofaune u specijalnom rezervatu prirode “Tivatska solila" za 2018. godinu. - Javno preduzeće za upravljanje morskim dobrom Crne Gore, Budva. [In Montenegrin]

Iković V., Gvozdenović, S. (2018): Population characteristics of Balkan terrapin (Mauremys rivulata) in Montenegro. In: Veselek, S., Popović, M., Šeat, J., Štih, A. (eds): Explore and protect the natural beauty of Balkans - International Rufford Small Grants Conference. - Association for sustainable development and habitat protection "HabiProt", Belgrade, Serbia; Herpetological Association in Bosnia and Herzegovina "ATRA", Sarajevo B\&H. (Abstract)

Irwin, M. J., Wright, P. C., Birkinshaw, C., Fisher, B. L., Gardner, C. J., Glos, J., Goodman, S. M., Loiselle, P., Rabeson, P., Raharison, J-L., Raherilalao, M. J., Rakotondravony, D., Raselimanana, A., Ratsimbazafy, J., Sparks, J. S., Wilmé, L., Ganzhorn, J. U. (2010): Patterns of species change in anthropogenically disturbed forests of Madagascar. - Biological Conservation 143: 2351-2362.

IUCN (2020): Global Red List. [https://www.iucnredlist.org/species/157274/ 747386]

Jablonski, D., Jandzik, D., Mikulíček, P., Džukić, G., Ljubisavljević, K., Tzankov, N., Jelić, D., Thanou, E., Moravec, J., Gvoždík, V. (2016): Contrasting evolu- 
tionary histories of the legless lizards slow worms (Anguis) shaped by the topography of the Balkan Peninsula. - BMC Evolutionary Biology 16: 99.

Jelić, D., Ajtić, R., Sterijovski, B., Crnobrnja-Isailović, J., Lelo, S., Tomović, Lj. (2013): Distribution of the genus Vipera in the western and central Balkans (Squamata: Serpentes: Viperidae). - Herpetozoa 25(3/4): 109-132.

Jelić, D., Kuljerić, M., Koren, T., Treer, D., Šalamon, D., Lončar, M., Podnar Lešić, M., Janev Hutinec, B., Bogdanović, T., Mekinić, S., Jelić, K. (2015): Crvena knjiga vodozemaca i gmazova Hrvatske. - Državni zavod za zaštitu prirode, Ministarstvo zaštite okoliša i prirode, Hrvatsko herpetološko društvo Hyla, Zagreb. [In Croatian]

Jovanović, M. (2009): Amphibia and Reptilia of Štoj plain (Ulcinj, Montenegro). Bulletin of the Natural History Museum 2: 137-152.

Ljubisavljević, K., Tomović, Lj., Urošević, A., Gvozdenović, S., Iković, V., Zagora, V., Labus N. (2018): Species diversity and distribution of lizards in Montenegro. - Acta Herpetologica 13: 3-11.

Mali, I., Brown, D. J., Ferrato, J. R., Forstner, M. R. J. (2014): Sampling freshwater turtle populations using hoop nets: Testing potential biases. Wildlife Society Bulletin 38(3): 580-585.

Marzahn, E., Mayer, W., Joger, U., Ilgaz, Ç., Jablonski, D., Kindler, C., Kumlutaş, Y., Nistri, A., Schneeweiß, N., Vamberger, M., Žagar, A., Fritz, U. (2016): Phylogeography of the Lacerta viridis complex: mitochondrial and nuclear markers provide taxonomic insights. - Journal of Zoological Systematics and Evolutionary Research 54: 85-105.

Mrdak, D. (2006): Biodiversity of Šasko lake. - Green Home, Podgorca. [http://www.greenhome.co.me/fajlovi/greenhome/attach_fajlovi/eng/main -pages/2012/11/pdf/Biodiversity_Assesment_Study_of_Sasko_Lake.pdf]

Pandey, P. D., Pandey, S. G., Devkota, K., Goode, M. (2016): Public perceptions of snakes and snakebite management: implications for conservation and human health in southern Nepal. - Journal of Ethnobiology and Ethnomedicine 12: 22.

Polović, L., Ljubisavljević, K. (2010): Herpetofaunal richness of the Skadar lake region, Montenegro: A review and update. - Scripta Scientiarum Naturalium 1: 113-121.

Polović, L., Čađenović, N. (2013): The herpetofauna of Krnovo (Montenegro). Natura Montenegrina 12(1): 109-115.

Polović, L., Čađenović, N. (2014a): The herpetofauna of the Great Ulcinj Beach area including Ada Island (Montenegro). - Turkish Journal of Zoology 38: 104-107.

Polović, L., Čađenović, N. (2014b): The herpetofauna of Ljubišnja Mountain, Montenegro. - Herpetozoa 26(3/4): 193-194.

Schmidt, B., Kranželić, D., Majetić, Đ., Lauš, B., Štih, A., Koren, T. (2020): Distribution and conservation status of the herpetofauna of Dugi Otok Island, Croatia. - Herpetozoa 33: 191-205.

Sillero, N., Campos, J., Bonardi, A., Corti, C., Creemers, R., Crochet, P-A., Crnobrnja-Isailović, J., Denoël, M., Ficetola, G. F., Gonçalves, J., Kuzmin, S., Lymberakis, P., de Pous, P., Rodríguez, A., Sindaco, R., Speybroeck, J., 
Toxopeus, B., Vieites, D. R., Vences, M. (2014): Updated distribution and biogeography of amphibians and reptiles. - Amphibia-Reptilia 35: 1-31.

Speybroeck, J., Beukema, W., Dufresnes, C., Fritz, U., Jablonski, D., Lymberakis, P., Martínez-Solano, I., Razzetti, E., Vamberger, M., Vences, M., Vörös, J., Crochet, P. A. (2020): Species list of the European herpetofauna - 2020 update by the Taxonomic Committee of the Societas Europaea Herpetologica. Amphibia-Reptilia 41: 139-189.

Stešević, D., Šundić, M., Caković, D., Čurović, M., Mrdak, D., Malidžan Milošević, D., Iković, V., Vizi, A., Radonjić, M., Ćetković, I., Pejaković, M., Obradović, M. (2017): Akcioni plan biodiverziteta glavnog grada Podgorice Nacrt. [In Montenegrin] [https://podgorica.me/db_files/Urbanizam/Dokumen ta/nacrt_akcionog_plana___25.11.17.pdf]

Štih, A., Burić, I., Justić, H., Karaica, D., Jelić, D. (2013): Typhlops - istraživanje zmije sljeparice na Dugom otoku. - Udruga Hyla, Zagreb. [In Croatian]

Tomović, Lj, Ajtić, R., Crnobrnja-Isailović, J. (2004): Contribution to distribution and conservation of batrachofauna and herpetofauna on Bjelasica Mountain in Montenegro. - Monographs of the Centre for Biodiversity of Montenegro, University of Montenegro 1: 140-148.

Verligov, V., Hristov, G., Lukanov, S., Lambevska, A., Tzankov, N. (2016): First record of Ablepharus kitaibelii (Bibron \& Bory de Saint-Vincent, 1833) in Montenegro. - Biharean Biologist 10(1): 65-66.

Vujović, A., Iković, V., Golubović, A., Đorđević, S., Pešić, V., Tomović, Lj. (2015): Effects of fires and roadkills on the isolated population of Testudo hermanni Gmelin, 1789 (Reptilia: Testudinidae) in central Montenegro. - Acta Zoologica Bulgarica 67(1): 75-84.

Žagar, A., Cafuta, V., Drašler, K., Jagar, T., Krofel, M., Lužnik, M., Petkovska, V., Planinc, G., Sopotnik, M., Vamberger, M. (2013): A review of eleven shortterm reptile surveys in the Western Balkans. - Hyla 1: 3-18.

\section{Online Appendices:}

Appendix 1. - Unpublished records. 
280 GVOzDENOvić, S: REPTILES IN THE SETTLEMENT MAREZA (MonTENEGRO)

\title{
ДИВЕРЗИТЕТ ГМИЗАВАЦА НА ПОДРУЧЈУ НАСЕЉА МАРЕЗА (ЦРНА ГОРА)
}

\author{
ГВОЗДЕНОВИЋ СЛАЪАНА
}

\section{Р Е 3 И М Е}

Диверзитет гмизаваца и фактори угрожавања њихових популација истраживани су током априла и маја 2019. године у широј области насеља Мареза. Методологија је била заснована на активном тражењу и визуелном бележењу врста дуж дефинисаних трансеката. Укупно је забележено 20 врста гмизаваца, што представља удио од $55 \%$ у укупном броју до сада забележених врста гмизаваца у Црној Гори. У литератури је забележено присуство још две врсте на овом подручју. На основу добијених резултата, са укупно 22 забележене врсте, област Марезе се може сматрати „врућом тачком“ диверзитета гмизаваца у Црној Гори. Први налаз врсте Xerotyphlops vermicularis у овом подручју доприноси познавању дистрибуције ове врсте. Три забележене врсте (Emys orbicularis, Testudo hermanni и Elaphe quatuorlineata) су на Анексу II Директиве о стаништима. Ниједна од забележених врста не спада у групу рањивих, угрожених или критично угрожених врста. Готово све забележене врсте су заштићене националним законодавством. Главни фактори угрожавања популација гмизаваца у области Марезе су: урбанизација, фрагментација и уништавање станишта, пожари, дивље депоније, убијање од стране локалног становништва, као и страдање на путевима. 